\title{
ASSESSMENT OF SHEAR STRESSES FROM SHRINKAGE AND THERMAL DEFORMATION IN WOOD-CONCRETE BRIDGE BEAMS
}

\author{
K. FURTAK ${ }^{1}$,
}

The aim of the paper is to assess the values of shear (delaminating) stress in the composition plane between the concrete (RC) deck slab and wood girder from concrete shrinkage, and shrinkage and swelling of wood, as well as difference in temperature between the wood web and concrete slab.

\section{INTRODUCTION}

Composite structures have been used for over a hundred years. The classical solution of the steelconcrete type is composed of the steel girder and concrete (reinforced concrete) slab interacting with it [4]. Over the years other compositions of materials were used, including the best known concrete-concrete structures. Sometimes the slab of prestressed concrete was used. The classical concrete was replaced with fibre concrete [7] or lightweight concrete [10]. Instead of steel, aluminium [11] and timber girders [1, 4, 6, 8, 9, 12] were applied. Wood-concrete composite beams are not frequently used in engineering practice. It cannot be stated, however, that it is a closed subject in civil engineering, particularly in view of the increased use of glued laminated timber in construction. The special areas of their application are floors in buildings (especially for the purpose of strengthening the existing ones) and bridges. The use of composite wood-concrete in the floor structures usually requires increasing their load bearing capacity. In the case of bridges such compositions are chiefly used in new objects $[1,5,12]$. The quoted solutions are characteristic of just such objects. Their features include the great height of composite beams, considerable slenderness and height of the wooden web relative to the thickness of the concrete (RC) slab. Some examples $f$ the cross-section of such bridges are shown in Fig. 1.

\footnotetext{
${ }^{1}$ Prof., DSc., PhD., Eng., Cracow University of Technology, Faculty of Civil Engineering, Warszawska 24, 31-155 Cracow, Poland, e-mail.: kfurtak@pk.edu.pl
} 
In the traditional format the format the design of wood-concrete composite beams focuses first of all on gravity loads $[2,3]$. In such calculations the forces acting in the composition plane are assumed to be constant, equal to maximum ones. Such an approach is acceptable at the design stage, when it is necessary to ensure the bearing capacity under extreme load. However, it is not sufficient for a detailed analysis of the structure. In real life the problem in question is more complex. In the composition plane - apart from the stresses from gravity loads - there are residual stresses from the shrinkage of concrete and wood, as well as from the difference in temperature between the wood girder and concrete (RC) slab. The stresses from shrinkage (of concrete and wood) are accompanied by the creep in these materials. The present paper is focused on the analysis of the impact of concrete shrinkage deformations on the state of stress in the wood-concrete beams. Concrete creep as well as shrinkage and creep of wood were also taken into account. A separate solution is given for the impact of the temperature difference between the two component parts of the composite beams discussed. The deformations of beams induced by the shrinkage of concrete and wood and wood swelling are shown schematically in Fig. 2. Similarly, schematic diagrams of deformations caused by the temperature difference are given in Fig. 3.

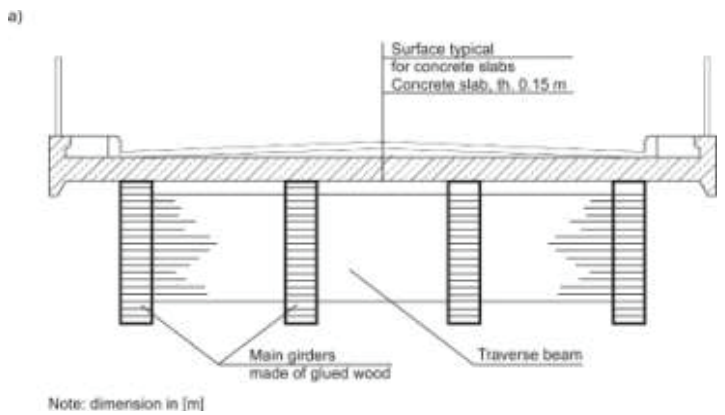




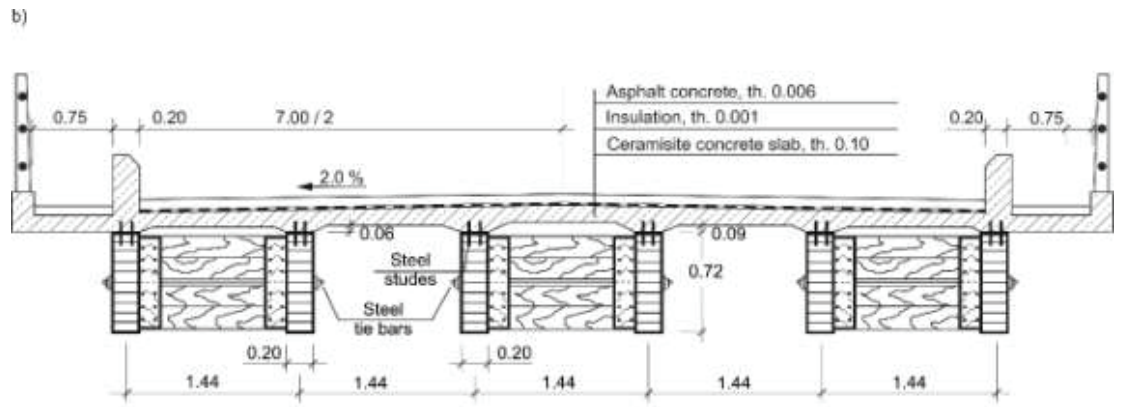

Note: dimension in $[\mathrm{m}]$

c)

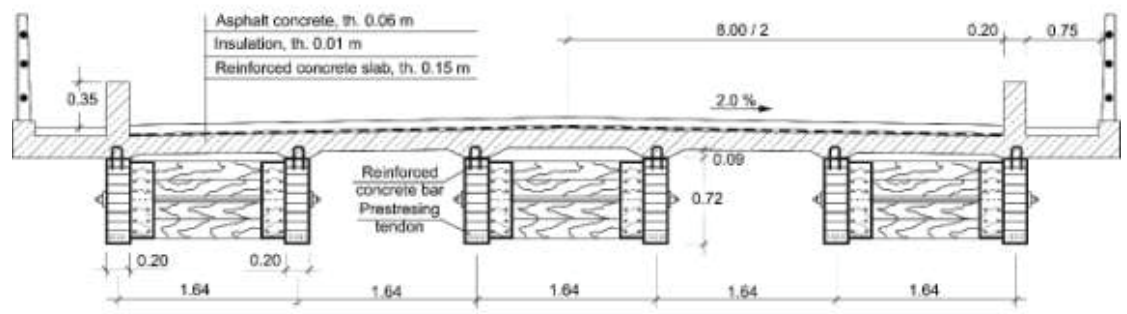

Note: dimension in $[\mathrm{m}$ ]

Fig.1. Examples of cross-sections of glued laminated timber - concrete composite bridges [1]:

$\mathrm{a}$ - standard cross-section, $\mathrm{b}$ - girders from glulam, $\mathrm{c}$ - girders from prestressed glulam 

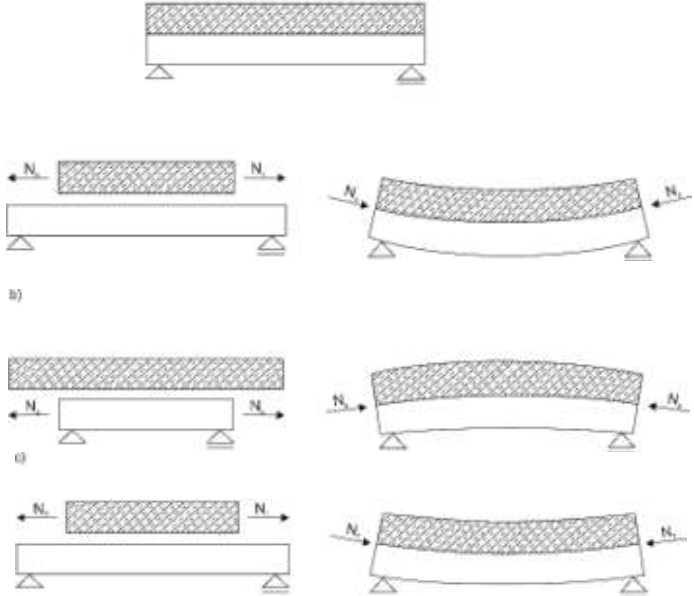

Fig. 2. Deformations of composite beams induced by: $a$ - concrete shrinkage, $b$ - wood shrinkage, $\mathrm{c}$ - wood swelling
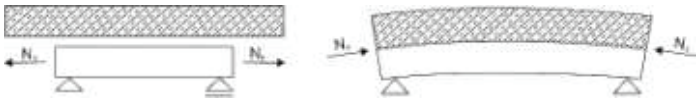

Fig. 3. Deformations of composite beams caused by temperature difference between wood girder and concrete $(\mathrm{RC})$ beam

\section{GENARAL ASSUMPTIONS}

For the solution of the problem of the stress from shrinkage and thermal deformations, in the woodconcrete beams the validity of the principle of superposition and plane section was adopted. Thus, work in the elastic range was assumed. It was also assumed that the neutral axis of the composite section passes through the wood girder (cf. Fig. 4). The last of the assumptions are satisfied by the high beams interacting with a relatively thin concrete slab, characteristic of bridges. 


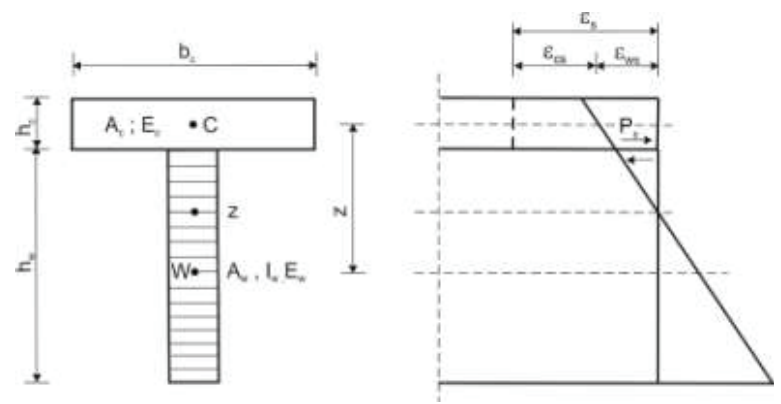

Fig. 4. Cross-section of a wood-concrete composite beam

In the proposed solutions the slip in the composition plane only under the load of concrete shrinkage, wood shrinkage and swelling, and temperature difference between the wood girder and concrete slab was disregarded. It is a simplification on account of the flexibility of connectors and upset of wood in the vicinity of connectors. However, such an assumption does not result in significant inaccuracies of calculation results owing to low values of the stress of the pressure between the connector and wood (even considering the permanent loads acting after the slab concrete has hardened). The deformations from unrestrained shrinkage of concrete are much larger than unrestrained shrinkage or swelling of wood. This is why they were taken into account jointly, adding the deformations respectively. Such an approach was presented in $[6,8]$. Wood creep was included by changing its modulus of elasticity. Concrete creep was included following one of the modified theories of ageing which assumes partial reversibility of creep deformation and time dependent alteration of the modulus of elasticity. The proposals suggested in [4] were used. The temperature difference between the wood girder and concrete slab was adopted as one for bridges, following [3]. When the temperature difference was taken into account, creep was neglected - the impact of temperature was treated as short-term. Two possible cases were considered: the temperature of the slab is higher than that of the wood girder and the temperature of the concrete slab is lower than that of the wood girder. The latter case is more unfavourable since its effects are added to the effects of concrete shrinkage deformation.

\section{SHEAR STRESSES IN COMPOSITION PLANE}

\subsection{STRESS FROM TEMPERATURE DIFFERENCE}

In order to specify the values of shearing forces (delaminating) from the difference in temperature between the wood girder and concrete slab an element of unit length $d x$ is analysed. The crosssection of this element is shown in Fig. 5a. This element is under the action of the force system 
presented in Fig. 5b. To enable marking the acting forces, in the figure a space was left between elements of the section, with an explanation that its value is zero. The force system shown in Fig. $5 \mathrm{~b}$ can be reduced to a system presented in Fig. 5c. Using the condition of equilibrium of forces projection onto the horizontal axis we obtain:

$$
N_{T}+t_{T} d x=N_{T}+d N_{T}
$$

hence:

$$
t_{T}=\frac{d N_{T}}{d x}
$$

Assuming the inseparability of the deformations of slab concrete and wood girder in the composition plane, it can be assumed that shear stress $t_{T}$ (it can be defined as the intensity of an elastic composition) is:

$$
t_{T}=c_{T} u_{T}
$$

where:

$c_{T}$ - coefficient of the composition flexibility; it can be adopted as $c_{T}=0,85 E_{c}$ [4],

$u_{T}-$ shift in the direction of the longitudinal axis of analysed section $x$ in the composition plane.

a)

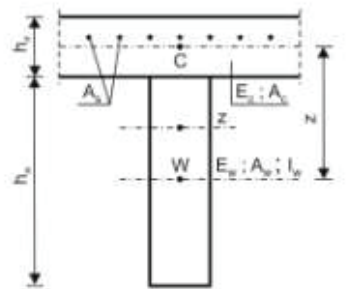

b)

c)

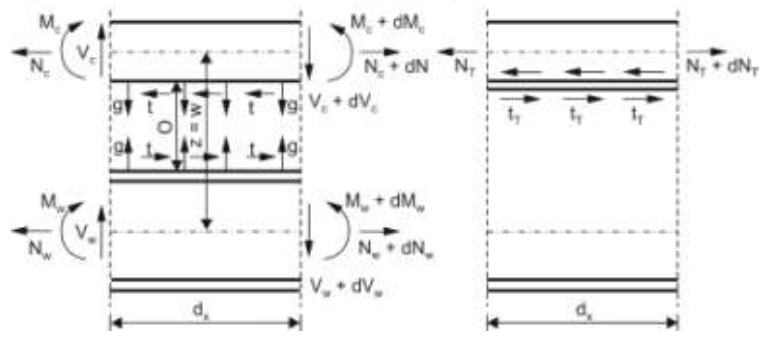

Fig. 5. Composite beam: a - cross-section, $\mathrm{b}$ - forces system, $\mathrm{c}$ - reduced forces system 
Using the given dependencies and taking into account the fact that the slab cross section is under the action of a force applied to its edge (at the level of the composition plane) we obtain after transformations:

$$
N_{T}^{\prime \prime}+c_{T} \varepsilon_{T}-c_{T} \frac{4 N_{T}}{E_{c} A_{c}}=0
$$

Unit unrestrained thermal deformation $\varepsilon_{T}$ is:

$$
\varepsilon_{T}=\alpha_{T} \Delta T
$$

where:

$\alpha_{T}$ - coefficient of thermal expansion,

$\Delta T$ - difference in the temperature between the concrete (RC) slab and wood girder.

The solution of equation (4) is the formula [4]:

$$
N_{T}=\varepsilon_{T}^{\prime} E_{c} A_{c}\left\{1-\frac{\cosh [m(l-x)]}{\cosh (m l)}\right\}
$$

where:

$$
\begin{aligned}
& \varepsilon_{T}^{\prime}=\frac{\varepsilon_{T}}{1+\delta} \\
& \delta=\frac{\delta_{w}}{\delta_{c}}
\end{aligned}
$$

$\delta_{w}-$ stiffness index of the wood girder

$$
\delta_{w}=\frac{1}{E_{w} A_{w}}+\frac{z^{2}}{E_{w} I_{w}}
$$

$\delta_{c}-$ stiffness index of the concrete slab

$$
\delta_{c}=\frac{1}{E_{c o} A_{c}}
$$

$E_{w}, A_{w}, I_{w}$ - modulus of elasticity of wood, cross section and moment of inertia of the wood girder,

$E_{c o}, A_{c}$ - initial modulus of elasticity of concrete (at time $t=0$ ) and cross-sectional area of the concrete slab, $z$ - arm of interior forces.

The steady stress in the composition plane from the difference in temperature is:

$$
\tau^{T}=\frac{d N_{T}}{d x}=\frac{0,85 E_{c o}}{m k_{3 c}} \frac{\varepsilon_{T}}{(1+\delta)} \frac{\sinh [m(l-x)]}{\cosh (m l)}
$$

The highest value of the above stress occurs at the ends of element $(x=0, x=2 l)$ and is:

$$
\tau_{\max }^{T}=\frac{0,85 E_{c o}}{m k_{3 c}} \frac{\varepsilon_{T}}{(1+\delta)} \operatorname{tgh}(m l)
$$


where:

$l$ - half length of the element,

$m$ - coefficient equal [4]:

$$
m=\sqrt{\frac{3.4}{A_{c}}}
$$

$k_{3 c}$ - coefficient covering the impact of time dependent change of modulus of elasticity of concrete:

$$
k_{3 c}=1-0,1 \varphi_{c}
$$

$\varphi_{c}-$ concrete creep coefficient (time-dependent; consequently, also $k_{3 c}$ is time-dependent).

\subsection{STRESS FROM CONCRETE SHRINKAGE}

The procedure of the calculation of stress from concrete shrinkage is similar to that of calculating the stress from temperature difference. Then we obtain:

$$
\tau^{S c}=\frac{p_{c}}{m} \frac{\sinh [m(l-x)]}{\cosh (m l)}
$$

and

$$
\tau_{\max }^{s c}=\frac{p_{c}}{m} \operatorname{tgh}(m l)
$$

where:

$$
\begin{aligned}
& p_{c}=c_{T} \varepsilon_{s c}=0,85 E_{c o} \varepsilon_{s c} \\
& \varepsilon_{s c}=\frac{\varepsilon_{s}}{\delta+k_{2 c}}
\end{aligned}
$$

$k_{2 c}-$ coefficient covering concrete creep:

$$
k_{2 c}=1+0,8 \varphi_{c}
$$

$\varepsilon_{s}$ - unit unrestrained shrinkage deformation.

Taking into account the flexibility of the wood girder and concrete creep we finally obtain:

$$
\begin{gathered}
\tau^{S c}=\frac{0,85 E_{c o}}{m k_{3 c}} \frac{\varepsilon_{s}}{\delta+k_{2 c}} \frac{\sinh [m(l-x)]}{\cosh (m l)} \\
\tau_{\text {max }}^{S C}=\frac{0,85 E_{c o}}{m k_{3 c}} \frac{\varepsilon_{s}}{\delta+k_{2 c}} \operatorname{tgh}(m l)
\end{gathered}
$$




\subsection{DEFORMATION FROM WOOD SHRINKAGE}

Deformation from the shrinkage (and swelling) of wood can be calculated in a similar way as in the calculation of deformation from concrete shrinkage. Another method (more favourable) is to add algebraically the deformations from the unrestrained shrinkage of concrete $\varepsilon_{s}$ and wood $\varepsilon_{s w}$. Then, the shrinkage deformation of wood is adopted with a sign opposite to the shrinkage deformation of concrete, in the case of swelling with the same sign. Wood creep can be included by inserting in formulae (20) and (21) the modified modulus of elasticity of wood $E_{w t}$

$$
E_{w t}=\frac{E_{w 0}}{k_{3 w}}
$$

instead of the modulus of elasticity of concrete, where :

$E_{w 0}-$ modulus of elasticity of wood at time $t=0$,

$k_{3 w}$ - coefficient the value of which can be calculated from formula:

$$
k_{3 w}=1-0,1 \varphi_{w}
$$

$\varphi_{w}$ - creep coefficient for wood (its value is time dependent, so, consequently, coefficient $k_{3 w}$ also is time dependent).

\section{ANALYSIS OF THE PROPOSED SOLUTION}

The analysis of the proposed solutions was performed with the initial assumptions on the geometry of the investigated composite girder as follows: $b_{c}=1,00 \mathrm{~m}, \quad h_{c}=0,20 \mathrm{~m}, E_{c 0}=34 \mathrm{GPa}, b_{w}=0,30$ $\mathrm{m}, h_{w}=2,00 \mathrm{~m}, E_{w 0}=12 \mathrm{GPa}$, Hence, $A_{c}=0,20 \mathrm{~m}^{2}, A_{w}=0,60 \mathrm{~m}^{2}, I_{w}=0,20 \mathrm{~m}^{4}, z=1,10 \mathrm{~m}$.

The adopted boundary value of the creep coefficient of concrete was $\varphi_{c \infty}=3,20$, that of wood $\varphi_{w \infty}$ $=0,60$. The value of unrestrained shrinkage of concrete was adopted as equal to $\varepsilon_{s c}=3,2 \cdot 10^{-4}$, that of wood (parallel to the fibres) $\varepsilon_{s w}=0,3 \cdot 10^{-4}$. The same value can be adopted for wood swelling. The assumption made in drawing the diagrams - which should be treated as an illustration of the problem rather than a presentation of precise results of the analysis - was a similar time course of the deformations from concrete shrinkage, and creep of concrete and wood, although the real course is different (cf. Fig. 6). From the practical point of view, the adopted assumption is not significant for the final values, for $t \rightarrow \infty$. With these assumptions we obtain:

$$
\begin{aligned}
& \delta_{c}=0,147 \frac{1}{G N}, \quad \delta_{w}=0,643 \frac{1}{G N}, \quad \delta=4,374, \\
& k_{2 t}=2,92, \quad k_{2 w}=1,30, k_{3 t}=0,68, \\
& k_{3 w}=0,94, m=4,123 .
\end{aligned}
$$




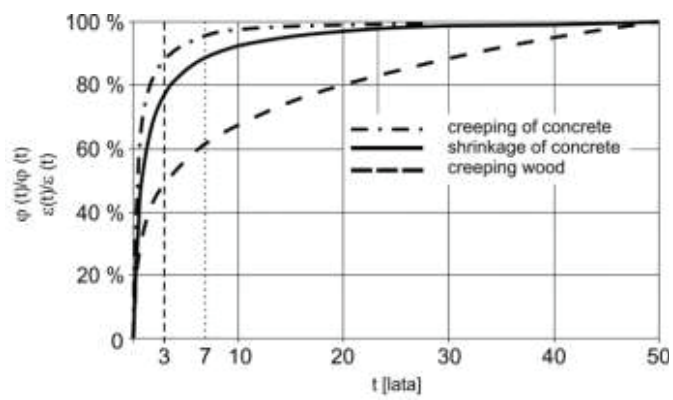

Fig. 6. Time course of relative (referred to the maximum ones) values of shrinkage deformations of concrete, and the creep coefficient of concrete and wood [8]

A detailed analysis was performed for beams of the length of $2 l=15,00 \mathrm{~m}, 2 l=20,00 \mathrm{~m}, 2 l=25,00$ m. The results of the analysis are shown in Fig. 7, 8 and 9. Fig. 7 illustrates the dependence of the shear (delaminating) stresses between the concrete slab and wood girder depending on the beam span. Fig. 8 illustrates a similar dependence, but on the $\mathrm{X}$-axis a relative distance of the analysed cross-section referred to the half span was adopted.

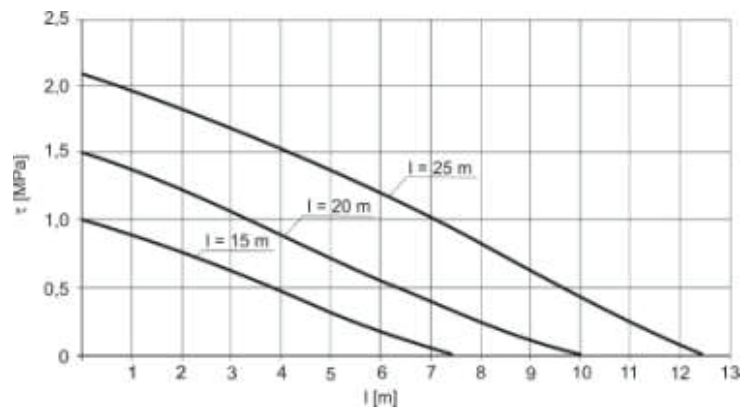

Fig. 7. Impact of beam span on shear (delaminating) stresses 


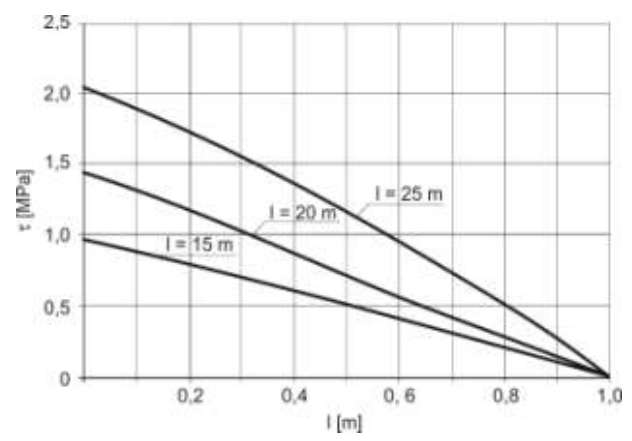

Fig . 8. Impact of the location of the analysed cross-section relative to beam span on shear (delaminating) stresses

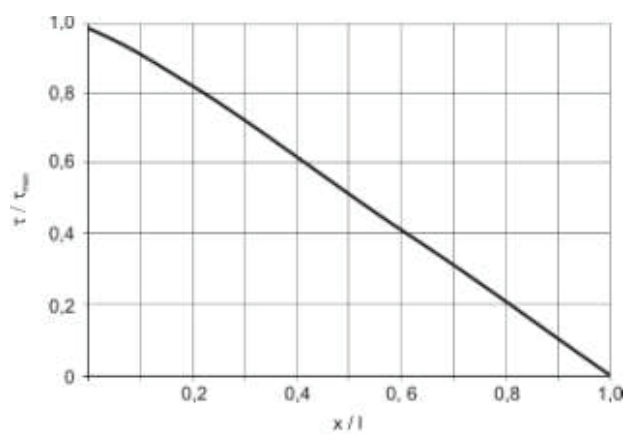

Fig. 9. Impact of the location of the analysed cross-section relative to beam span on the relative value (referred to the maximum one) of the shear (delaminating) stress

The diagram shown in Fig. 9 illustrates the dependence of the relative value of the delaminating stress referred to the maximum value (for $x=0$ ) depending on the relative distance (referred to beam half span) of the analysed cross-section. It is practically a graphic presentation of the final fraction of formula (11). Based on the results of the analysis of the proposed solutions it can be stated that the value of the delamination stress highly depends on the beam span. The impact of the parameters related to concrete shrinkage and creep and creep, shrinkage or swelling of wood follows directly from the provided formulae. The effect of deformations from shrinkage or swelling of wood can be added algebraically to the effect of shrinkage deformations of concrete. A separate analysis was performed in the range of the impact of creep of concrete and wood. This impact can be easily interpreted by the analysis of the second fraction of formula (11), with coefficients $\delta$ and $k_{2}$ in the denominator. If the results of calculations excluding creep are adopted as basic, then if creep and the time-changed modulus of elasticity of concrete and wood are included, the value of 
the delaminaing stress will be reduced by $37,85 \%$. The effect of the creep of wood is but minor and is less than $10 \%$. The thermal deformations are $\varepsilon_{T}=\alpha_{T} \Delta T$. According to [3], the difference in temperature is $13^{\circ} \mathrm{C}$ when the slab is heated $3,5^{\circ} \mathrm{C}$ at the slab load relative to the wood girder. Although in the case of slab heating higher values of $\Delta T$ are adopted, it should be noted that this effect is not subtracted from the shrinkage deformation of the concrete slab. The reliable value of the thermal deformation is $\varepsilon_{t}=10^{-5} \cdot 7=0,7 \cdot 10^{-4}$. This deformation is considerably lower than that from concrete shrinkage. The value of the shear stress between the concrete slab and glulam girder is also affected by the girder's height. The results of analysis in this area are shown in Fig. 10. The curves were plotted for the beam span of $2 l=15,00 \mathrm{~m}$. The solid line indicates the girder of $h_{\mathrm{w}}=2,00 \mathrm{~m}$ in height, while the broken line refers to the girder of the height of $h_{\mathrm{w}}=1,50$ $\mathrm{m}$. The values of the stress lower by ca. $18 \%$ are found in the case of a lower girder. This results from a lower resistance of the girder against concrete shrinkage.

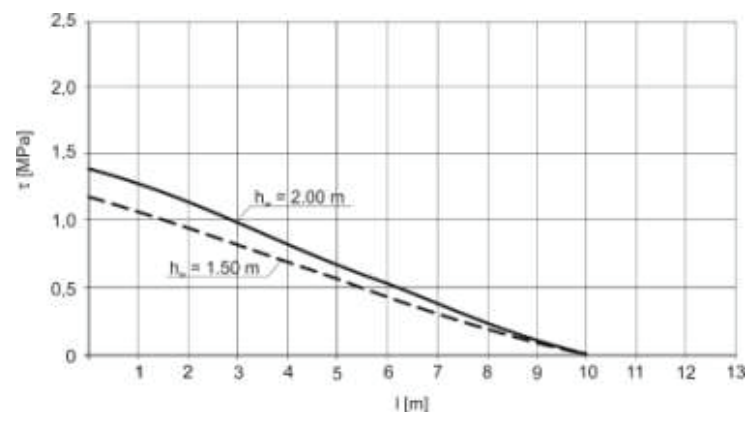

Fig. 10. Shear (delaminating) stress for various heights of wood girders

\section{REMARKS AND FINAL CONCLUSIONS}

The aim of the paper is to assess the values of shear (delaminating) stress in the composition plane between the concrete (RC) deck slab and wood girder from concrete shrinkage, and shrinkage and swelling of wood, as well as difference in temperature between the wood web and concrete slab. The analysis was performed for concrete-wood composite beams, on elements characteristic of bridges. The creep of concrete and wood were also taken into account. The study has shown that the value of the stresses discussed is heavily affected by the composite beam span. Moreover, based on the analysis of the provided formulae, the impact of geometric parameters and the value of unrestrained shrinkage on delaminating stresses can be specified. These may be higher than the natural adhesion of concrete to wood (glued laminated timber). The reduction in the value of the 
stresses from concrete shrinkage results from concrete creep. The effect of wood creep and the stress from the shrinkage or swelling of wood is significantly lower. In practical applications the deformation from concrete shrinkage can be added to that from wood swelling. The case is reverse for wood shrinkage, where these deformations should be subtracted from those from concrete shrinkage. The impact of the difference in temperature $\Delta T$ between the concrete (RC) slab and wood girder is much lower than that of concrete shrinkage. This results from the values of $\Delta T$ recommended in the Eurocode [3]. In the case of delaminating stresses from $\Delta T$ the creep of concrete and wood is disregarded assuming that the impact of temperature difference is short-term although repeated many times.

\section{REFERENCES}

[1] Biliszczuk J., Bień J., Maliszkiewicz P.: Mosty z drewna klejonego. [Bridges from glued laminated timber.] Wydawnictwa Komunikacji i Łączności. Warszawa, 1988 [in Polish].

[2] EN 1995-1-1. Projektowanie konstrukcji drewnianych. Zasady generalne i zasady dla budynków. [Design of timber structures. General - Common rules and rules for buildings.]

[3] EN 1995-2. Projektowanie mostów drewnianych. [Design of timber structures.]

[4] Furtak K.: Mosty zespolone. [Composite bridges.] PWN. Warszawa 1999 [in Polish].

[5] Furtak K.: Mosty drewniane.[ Timbers bridges.] Politechnika Krakowska 2002 [in Polish].

[6] Gelfi P., Giuriani E., Marini A.: Stud Shear Connection Design for Composite Concrete Slab and Wood Beams. Journal of Structural Engineering. December 2002.

[7] Holschemacher K., Klotz S., Köhler S.: Verbunddecken aus Stahlfaserbeton und Holz. Beton- und Stahlbetonbau, 99 (2004), Heft 1.

[8] Kuhlmann U., Schänzlin J., Michelfelder B.: Berechnung von Holz-Beton-Verbunddecken. Beton- und Stahlbetonbau, 99 (2004), Heft 4.

[9] Resch E., Schmidt J., Kaliske M., Schneider W.: Betrachtungen zur Verkehrslastannahme bei Holzbalken/Beton-Verbunddecken. Beton- und Stahlbetonbau, 99 (2004), Heft 10.

[10] Steinberg E., Selle R.,Faust T.: Connectors for Timber-Lightweight Concrete Composite Structures. Journal of Structural Engineering. November 2003.

[11] Szumigała M., Chybiński M., Polus Ł.: Preliminary Analysis of the Aluminum-Timber Composite Beams. Civil and Environmental Engineering Reports. 2017.

[12] Zobel H., Alkhafaji T.: Mosty drewniane. [Timbers bridges.] Wydawnictwa Komunikacji i Łączności. Warszawa 2006 [in Polish].

\section{LIST OF FIGURES}

Figure 1. Examples of cross-sections of glued laminated timber - concrete composite bridges [1]: a standard cross-section, $\mathrm{b}$ - girders from glulam, $\mathrm{c}$ - girders from prestressed glulam Rysunek 1. Przykładowe przekroje poprzeczne mostów o konstrukcji zespolonej typu drewno klejone beton [1]: a - przekrój typowy, b - dźwigary drewniane z drewna klejonego, c - dźwigary ze sprężonego drewna klejonego 
Figure 2. Deformations of composite beams induced by: a - concrete shrinkage, b - wood shrinkage, c wood swelling

Rysunek 2. Odkształcenia belek zespolonych pod wpływem: a - skurczu betonu, b - skurczu drewna, c pęcznienia drewna

Figure 3. Deformations of composite beams caused by temperature difference between wood girder and concrete (RC) beam

Rysunek 3. Odkształcenia belek zespolonych pod wpływem różnicy temperatury między dźwigarem drewnianym i płytą betonową

Figure 4. Cross-section of a wood-concrete composite beam

Rysunek 4. Przekrój poprzeczny belki zespolonej typu drewno-beton

Figure 5. Composite beam: $\mathrm{a}$ - cross-section, $\mathrm{b}$ - forces system, $\mathrm{c}$ - reduced forces system Rysunek 5. Belka zespolona: a - przekrój poprzeczny, b - układ sił, c-zredukowany układ sił Figure 6. Time course of relative (referred to the maximum ones) values of shrinkage deformations of concrete, and the creep coefficient of concrete and wood.

Rysunek 6. Przebieg w czasie względnych (odniesionych do maksymalnych) wartości odkształceń skurczowych betonu oraz współczynnika pełzania betonu i drewna

Figure 7. Impact of beam span on shear (delaminating) stresses

Rysunek 7. Wpływ rozpiętości belki na wartość naprężeń ścinających (rozwarstwiających)

Figure 8. Impact of the location of the analysed cross-section relative to beam span on shear (delaminating) stresses

Rysunek 8. Wpływ położenia rozpatrywanego przekroju względem rozpiętości belki na wartość naprężeń ścinających (rozwarstwiających)

Figure 9. Impact of the location of the analysed cross-section relative to beam span on the relative value (referred to the maximum one) of the shear (delaminating) stress

Rysunek 9. Wpływ położenia przekroju względem rozpiętości belki na wartość względną (odniesioną do maksymalnej) naprężenia ścinającego (rozwarstwiającego)

Figure 10. Shear (delaminating) stress for various heights of wood girders

Rysunek 10. Porównanie wartości naprężeń ścinających (rozwarstwiających) dla różnych wysokości dźwigarów drewnianych

Received 15.06.2019 